\title{
AN OVERVIEW ON MANAGING CHANGES FOR BANK RISKS IN TIMES OF FINTECH (R)EVOLUTION: A CHALLENGE OR OPPORTUNITY?
}

\author{
Artina Bedjeti Baftijari \\ National Bank of the Republic of North Macedonia \\ artinabexheti@hotmail.com \\ Leonid Nakov \\ Faculty of Economics - Skopje, Ss. Cyril and Methodius University \\ leonid.nakov@eccf.ukim.edu.mk
}

\begin{abstract}
Most of the economic activities are becoming highly digital. In the past several years changes in the technological improvements and financial innovations had an enormous impact on the modern financial system. Worldwide, the banking industry has changed and integrated the financial technology (FinTech) in its everyday routine. Nowadays, for some financial members FinTech provides a big threat and a challenge for the traditional banking, while for some others it provides an opportunity for more flexibility, better service functionality and higher service quality. Overall, banks adopt innovations to satisfy customers' demands, despite the risks and challenges imposed from FinTech and new financial product development (NFPD). In general banks benefit from opportunities of the new product development in the aspect of allocating more efficiently the resources, reduction in transaction costs, promotion, revenue growth and profitability. The aim and objective of this paper is to identify and evaluate the main risks related to development of FinTech and financial innovations that banks are exposed to (on micro and macro level), and to provide recommendations on the reduction of those risks and controlling them. Based on literature review, researches proved that one of the major obstacle to firm 's innovativeness is the negative impact of the new financial product development on banking risks. It is recommended that in times of technological boom commercial banks should invest their available funds in suitable techniques for successfully accepting new financial product development.
\end{abstract}

Keywords: FinTech, Financial innovation, Managing changes, Commercial banks, New financial product development

JEL classification: $G 21,033$

\section{INTRODUCTION}

The banking industry worldwide has dramatically changed as a result of the growing use of technology on their every day basis. Financial technology (FinTech) along with the importance of innovations poses an important issue on the global economy. Nowadays, the banking industry is increasingly facing competition from nonfinancial institutions as a result of FinTech, making them think beyond traditional financial services, find more innovative solutions to survive during the technological boom and serve the demands of their customers. For the traditional banking FinTech is an evolution rather than revolution since it is diversifying and supplementing the existing system. So, rethinking to increase investment in FinTech is of a real high importance. 
As a result of such revolution of the financial services because of the involvement of FinTech in the banking industry, many researchers believe that it imposes a big threat to the traditional banks facing different operational risks. Still some other researchers believe that FinTech poses a challenge which can be reflected as an opportunity for providing better service functionality and higher service quality, allocating more efficiently the resources and reduce the transaction costs of their services.

Overall, FinTech startups and banks have a lot to offer to each other. Fintech as new generations are quick adopters of changes and have more technical expertise, while banks on the other hand have stable assets, know-how expertise, stable infrastructure and large loyal customer base. Working together rather than competing against each other can be far more successful at improving the financial services and customer experience (Carey, 2018). In general, identifying the risks and opportunities of FinTech (r)evolution and new financial product development (NFPD) in this cosmopolitan economy seems of a high significance and importance.

Moreover, banks are better at monitoring and screening their clients like households and enterprises, making them better players in capital buffering, credit riskiness and deposit insurance. Clearly, in the world most of FinTech companies act as brokers, and in this case investors are left with higher insecurity and credit risk. Therefore, FinTech companies have riskier liabilities and asset portfolio then banks (Navaretti, et al., 2018).

The aim and objective of this paper is to identify and evaluate the main risks related to development of FinTech and financial innovations that banks are exposed to (on micro and macro level), and to provide recommendations on the reduction of those risks and controlling them. The scientific problem that is presented in this overview paper studies the fact that there is no clear evidence of risks imposed on the banking industry by the FinTech revolution through quantitative analysis methods. Therefore, the use of broader literature review, experts' evaluation (secondary data) and qualitative analysis are used to elaborate the problem of managing changes for banks in such revolutionary times.

\section{LITERATURE REVIEW}

Banks are institutions whose role is to collect deposits from the public and grant loans. Simultaneously, they are conducting three activities at the same time: transforming financial liabilities to assets, payment services and processing and collecting information (Freixas and Rochet, 2008). All of these are some kind of risks, and if they are not managed or controlled, bank runs can occur. Nowadays, banks are facing an increasing competition from FinTech companies, who are expanding their interference in the traditional services conducted by banks. But, it is a real threat or not is neither true nor false. All these depend on the steps that banks and FinTechs will undertake in the following years if they will want to compete or complete each other (Temelkov, 2018).

Since, in the last couple of years the traditional way of banking is marked with different challenges, financial services and activities have changed a lot. As a result, in the banking industry worldwide the importance of technological innovations is growing rapidly, they are expanding the range of their activities, making the link between banks and FinTech start-ups complementary. The following figure represents the evolution of financial technology in the financial sector through years: 
Figure 1. FinTech - The digital (R)evolution in the financial sector

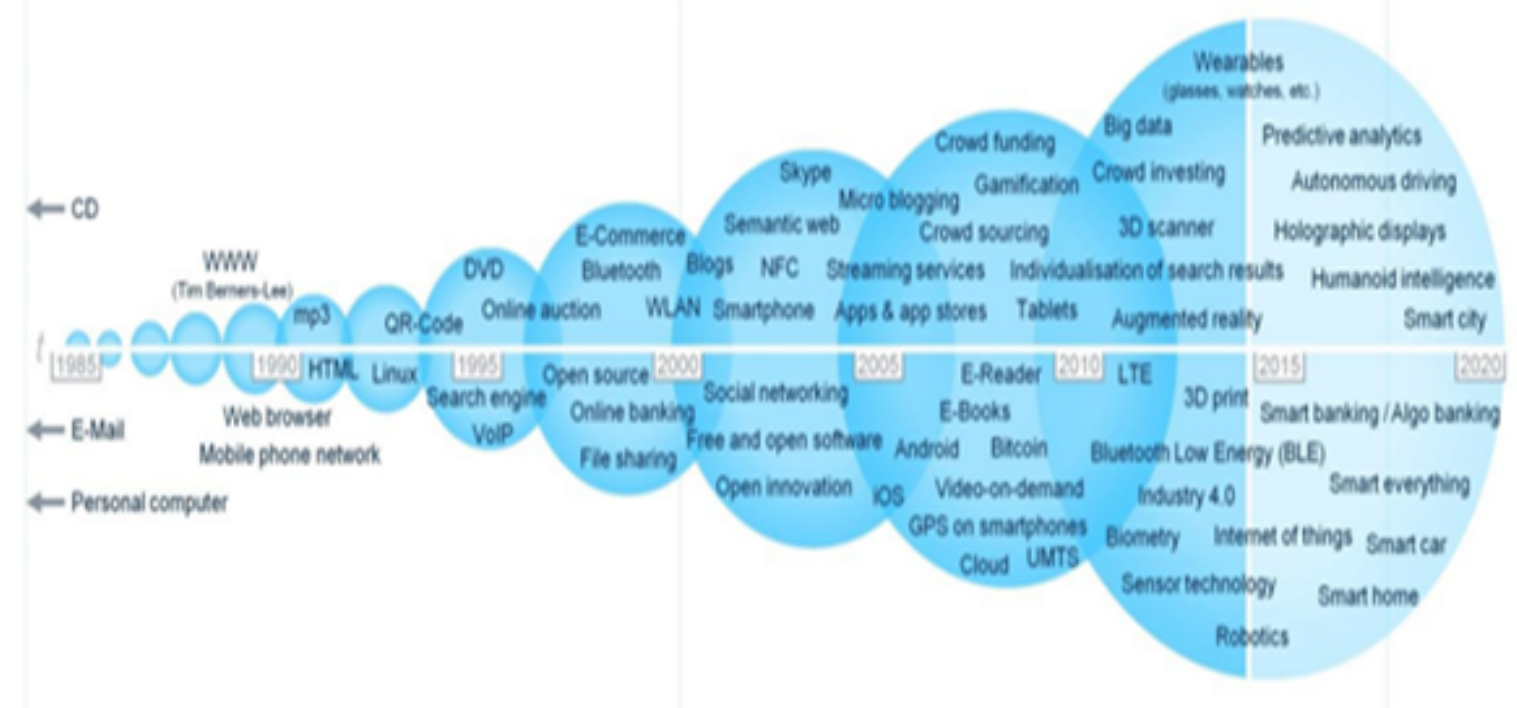

Web 1.0

Web 20

Web 3.0

reduction in product life cycles \& increase in innovation intensity

Source: (Dapp, et al., 2014)

Another challenge is the regulatory compliance, and the adoption to constantly evolving regulations and the implementations for banks are expensive activities (Wong, 2017). In particular, for some categories of clients they experience an increase in regulations, especially those that are more risky. On the other hand, the new players such as FinTech companies have loosed regulatory framework in a way that they have a cost advantage over the banks in financing their clients (Temelkov, 2018). Consequently, the FinTech companies are entering the financial markets because of these underserved categories of clients who seek alternative ways of accessing financial funds and services, strengthening their position in the future (Wardrop et al., 2016). Also, traditional banks suffer from another weakness such as their complex bureaucracy and corporate structure, making costs even higher, while FinTech companies do not have such a complicated organizational structure for now.

Furthermore, in order banks to survive the big threat from technological innovations, they have to undergo the process of new financial product development (NFPD). Inventing a new financial product means to catch up with the latest trends, in a way of reducing growth instability, allocate more efficiently the resources and enable banks to have greater access to financial services (Dewati, 2015). But, the whole process of introducing NFPD has taken some steps accompanied with different psychological effects with time, as follows: 
Figure 2. The five stages in an innovative technology's adoption life cycle
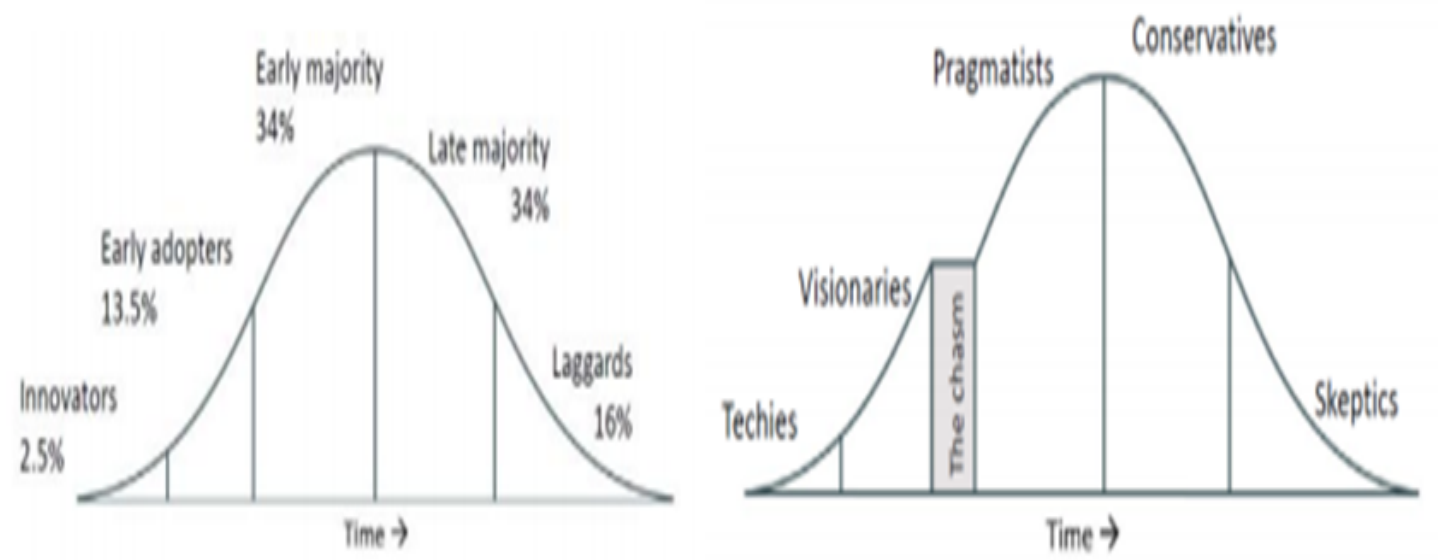

Source: (Aaron, et al., 2017)

According to Wadesango et al. (2017), there are benefits and challenges associated with the development of new financial products. Benefits like saving the market share and keeping the customer base high, providing services with higher quality and less resources, etc. As a challenge it can be taken into account the fact that NFPD has a negative effect on profitability and liquidity constrains.

\section{THE IMPACT OF FINTECH AND NFPD ON TRADITIONAL BANKING}

The rise of innovations and FinTech companies are posing high risks of various natures in the establishment of banking services. One of the very known is the liquidity risk that banks face in their everyday activities with the appearance of technological innovations. From researches' perspective an interesting question rises if FinTech companies do trigger liquidity issues in the financial system (Navaretti et al., 2018). Some of them say yes because they can act like a pool of funds when clients can make withdrawals whenever they need. While some others say no, because if FinTech companies issue loans and create less liquid assets in that way they will need a specific authorization to act like banks. In a way, banks are much more trustable institutions and relay under sticker regulations in emerging industries and developing countries.

Moreover, each new FinTech company in the future may offer only one service from the traditional banking, and the biggest danger of FinTech's impact on the banking industry is the fact that they will offer services at lower cost with higher accessibility. That is why because of the potential losses in revenues or benefits a lot of banks in the future will consider cooperation with FinTech companies, but each cooperation has pros and cons during its operation as follows:

Table 1. Risks and benefits associated from cooperation between banks and FinTechcomapnies

\begin{tabular}{|l|l|}
\hline \multicolumn{1}{|c|}{ Benefits } & \multicolumn{1}{|c|}{ Risks } \\
\hline Strengthen the brand reputation & Differences in culture \\
\hline Increase in mobile banking & Cybersecurity risks \\
\hline $\begin{array}{l}\text { Reduction in bank branches resulting in } \\
\text { lower capital expenditures }\end{array}$ & Difficult to find qualified workers \\
\hline
\end{tabular}




\begin{tabular}{|l|l|}
\hline $\begin{array}{l}\text { Attract new customers from different places } \\
\text { with less capital expenditures }\end{array}$ & Investing is risky \\
\hline Involvement of younger generations & Legislation and regulatory complexity \\
\hline & $\begin{array}{l}\text { Technical issues in integrating banks' and } \\
\text { FinTechs' functions. }\end{array}$ \\
\hline
\end{tabular}

Source: (Manatt, 2016)

According to Temelkov (2018) traditional banking with the introduction of financial technology will face decreasement in customer base and higher profit loss which will initiated the necessity for banks to make alliance with FinTech companies. Also, many researches seriously consider the fact that banks should start partnering with FinTech companies if they want to have stable profits, if not, with the development of highly efficient competitors banks will realize a decrease in their revenues approximately from $29-35 \%$. On the other hand, if banks start the digitalization process and financial transformation on time, except from maintaining their position, they will also increase their profits.

Furthermore, with the implementation of the interaction between commercial banks and FinTech companies the analysis can be expended through different variables like costumer behavior, regulations, investments and technology trends. All of the taxonomy of the interaction can be very profitable in the future industry of banking. According to Vasiljeva and Lukanova (2016), in the below figure is presented a better taxonomy of the mentioned interaction:

Figure 3. The taxonomy of the interaction between FinTech and Banks with other variables

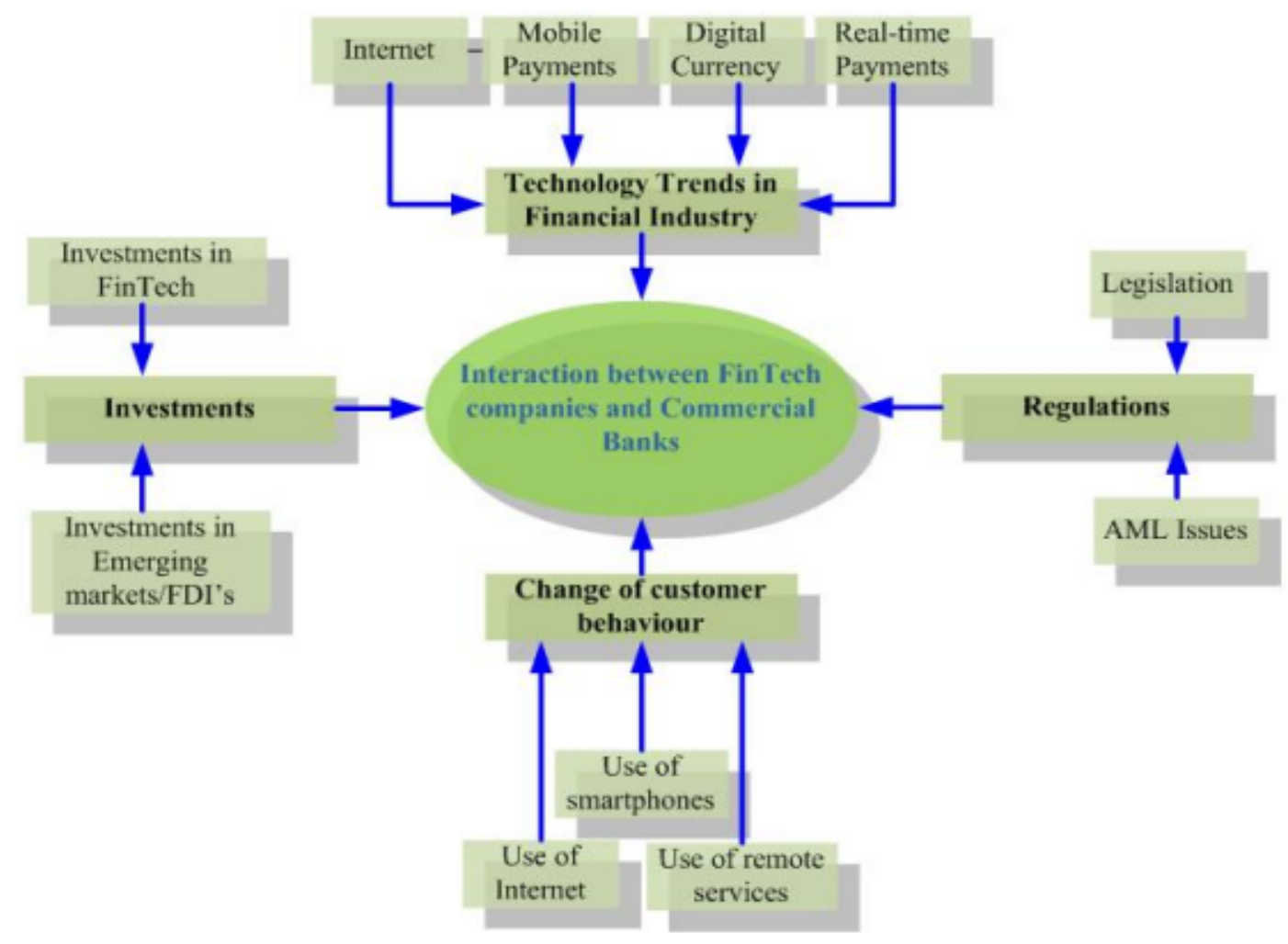

Source: (Vasiljeva\&Lukanova, 2016) 
In addition, if a new technology is indeed able to cross the financial system, the analysis then turns to whether the FinTech firm can secure a sustainable competitive advantage within the banking market. That is why despite the pros and cons of the cooperation between banks and FinTech start-up companies, banks should keep in mind the development of new financial techniques and the adoption of new financial product development (NFPD) as it is of a high significance and importance during the penetration in the digital world. Banks among themselves should consider the Porter's five forces when developing new financial products in order to catch up with the fast emerging financial technologies. The following table summarizes the Porter's approach:

Table 2. Porter's five forces

\begin{tabular}{|c|c|c|}
\hline Force & Description & Attributes \\
\hline Supplier bargaining power & $\begin{array}{l}\text { The amount of pressure } \\
\text { suppliers are able to place } \\
\text { on a business }\end{array}$ & $\begin{array}{l}\text { - Provider of funds }{ }^{29} \\
\text { - Knowledge experts }{ }^{30}\end{array}$ \\
\hline Customer bargaining power & $\begin{array}{l}\text { The amount of pressure } \\
\text { and/or influence customers } \\
\text { are able to place on a } \\
\text { business }\end{array}$ & $\begin{array}{l}\text { - Customer vs. } \\
\text { concentration } \\
\text { - Switching costs } \\
\text { - Substitutable products } \\
\text { - Price sensitivity }\end{array}$ \\
\hline Threat of new entrants & $\begin{array}{l}\text { The ease with which new } \\
\text { companies can enter the } \\
\text { industry }\end{array}$ & $\begin{array}{l}\text { - Cost advantages } \\
\text { - Economies of scale } \\
\text { - Barriers to entry } \\
\text { - Capital requirements }\end{array}$ \\
\hline Threat of substitutes & $\begin{array}{l}\text { The likelihood that a } \\
\text { customer will switch to a } \\
\text { competitive product or } \\
\text { service }\end{array}$ & $\begin{array}{l}\text { - Relative price and/or } \\
\text { performance } \\
\text { - Propensity for substitution } \\
\text { - Switching costs }\end{array}$ \\
\hline Competitive rivalry & $\begin{array}{l}\text { The intensity of competition } \\
\text { among existing firms in an } \\
\text { industry }\end{array}$ & $\begin{array}{l}\text { - Competitor concentration } \\
\text { - Capital intensity } \\
\text { - Growth prospects } \\
\text { - Exit barriers } \\
\text { - Product differentiators }\end{array}$ \\
\hline
\end{tabular}

Source: (Aaron, et al., 2017)

Each of the competitive forces can help reveal the root causes of an industry's current profitability and losses over time, provide a framework for influencing and anticipating competition in the financial system. However, today there are a lot of challenges and uncertainties in the financial world and analyzing the impact and riskiness is of a high importance when considering new financial product developments in the banking industry (Bervas, 2008).

Based on different studies, I can realize that the technological era in the banking industry is identified through a range of applications and functions, such as: upgrading the current products and services while reducing their prices, introducing new products in the banking market, promoting competition and introducing new business models. Moreover, the function of the regulatory body is a mixture of allowing further the development of financial technology and protecting the financial sector from any possible risks. Since the new trend of penetrating the 
market with technological innovations and FinTech companies is present worldwide, then the revenues of the banks by 2025 will be reduced by 10 to 30 percent.

\section{CONCLUSIONS AND RECOMMENDATIONS}

For many years banks enjoyed a comfort zone for conducting and offering their traditional financial services. Nowadays in the developing world, banks are facing major dangers from the technological innovations, including the potential entrance of FinTech companies. Thus, in order to survive, banks are willing to undergo several proactive activates to create values, save their market position and keep the customer base high. Therefore, the whole process of practicing to adopt new financial product development and information management technology innovations, together with the process of integration of banks and FinTechs in the future, refers to big opportunities and benefits for the financial market.

Based on researches, banks are working towards improving their efficiency in the process of automation, processing data and digitalization. Regardless of having strong market position while reliability and trust for FinTechs are not yet built, they continue to face challenges for conducting the traditional ways of banking. Even though FinTechs are not prone to strong regulations like banks, a future cooperation between these two financial forces can ease the access to financial sources and deliver perfect products and services for costumers. That is why it is recommended for commercial banks to emphasize their available funds and invest them in suitable techniques for successfully developing new financial products to apply the new era of customer preferences, penetrate successfully in the market and implement many new FinTech innovations or/and cooperation with the future availableFinTech companies.

Moreover, the rapid technological innovations and customers demand raise the need for employing skilled workforce, come up with new software and invent new financial products to maintain and reach the expectations of all the subjects of the economy. Many banks should involve themselves into innovations, especially in new financial products development (NFPD) to save themselves from any kind of difficulty or illiquidity. In such cases, all this requires banks to reorganize their product innovations in order to strengthen and keep their market share. Finally, banks have two choices. The first one is that they try to keep their market share though technological changes in their current business processes and the second choice is the possibility for a bank to enter into an agreement with a FinTech company. Instead of battling with the new competitors banks are initiating steps to enjoy the benefits offered by each other through technological innovations, increasing the profits and customer base.

\section{REFERENCES}

Aaron, M., Rivadeneyra, F. and Sohal, S. (2017), "Fintech: "Is this time different? A framework for assessing risks and opportunities for Central Banks", Bank of Canada Staff Discussion Paper 2017-10 (July). Canada: Bank of Canada.

Bervas, A., (2008), "Financial innovation and the liquidity frontier", FSR FINANCIAL, p.123.

Carey, S. (2018), "What are the biggest risks fintech poses to banks?" available at https://www.computerworld.com/article/3427766/what-are-the-biggest-risks-fintech-poses-tobanks-.html (accessed 13 January 2020)

Dapp, T., Slomka, L., AG, D.B. and Hoffmann, R. (2014), "Fintech-The digital (r) evolution in the financial sector", Deutsche Bank Research, pp.1-39.

Manatt, (2016) "Growing together: Collaboration Between Regional and Community Banks and Fintech", Manatt, Phelps \& Philips, LLP.

Navaretti, Barba, G., Calzolari, Manuel, J., \& F., A. (2018), "Fintech and Banking. Friends or Foes?" available at https://papers.ssrn.com/sol3/papers.cfm?abstract id=3099337 (accessed 16 May 2020) 
Temelkov, Z. (2018), "Fintech firms opportunity or threat for banks?", International Journal of Information, Business and Management, Vol.10 No. 1, pp.137-143.

Vasiljeva, T. and Lukanova, K., (2016). "Commercial banks and FINTECH companies in the digital transformation: Challenges for the future", Journal of Business Management, Vol. 11. Wadesango, N., Lora, N. and Charity, M., (2017). "A literature review on the effects of liquidity constraints on new financial product development." Academy of Accounting and Financial Studies Journal, Vol. 21 No.3, pp. 1-11.

Wardrop, R., Rosenberg, R., Zhang, B., Ziegler, T., Squire, R., Burton, J. \& Garvey, K. (2016), "Breaking new ground: The Americas alternative finance benchmarking report." available at https://ssrn.com/abstract $=3621308$ (accessed 8 July 2020)

Wong, P. (2017), "Fintech an opportunity, not a threat, to banking industry", China Daily Hong Kong. 